\title{
Pruritus in Cancer. Current Understanding and Treatment
}

\section{Abstract}

Pruritus in cancer is rare and heterogenous. In the past two decades our understanding of pruritus has dramatically increased and new therapies have emerged. New strategies and drugs are being introduced or are expected soon. An important concept concerning mechanism of pruritus in cancer is neuroinflammation, also in the periphery as well as in the spinal cord and brain, where Toll-like receptors on the surfaces of microglia and many other macrophages play a key role. These receptors are influenced by many existing drugs like opioids and opioid antagonists, serotonin reuptake inhibitors, and probably few others. Another strategy is disruption of signal transmission in the skin, spinal cord, and brain by the NK1 antagonists aprepitant, serlopitant, gabapentin, and pregabalin. None of the types of pruritus responds to antihistamines, and these drugs should be avoided.

Palliat Med Pract 2020; 14, 1: 16-21

Key words: pruritus, itch, cancer, paraneoplastic phenomenon, serotonin reuptake inhibitors, paroxetine, sertraline, gabapentin, pregabalin, aprepitant

\section{Introduction}

Pruritus accompanying malignant diseases is uncommon and diverse [1, 2]. It can be recalcitrant and can be a major clinical problem. Not such a long time ago our understanding of pruritus was limited to the fact that histamine injected subcutaneously caused intense itch and flare [3]. This mechanism, the only one known at the time, based on histamine release from the mast cells, proved to be entirely irrelevant in the treatment of severe pruritus in cancer, and now we know that non-histamine pathways of itch exist and demand different approaches [4]. Despite this, many clinicians still prescribe antihistamines for cancer-related pruritus. Sometimes they are helpful, but this is appears to be related more to the anti-cholinergic and sedative effects of older antihistamines [5].

In the past 25 years some new therapies of cancer-related pruritus have been developed. Most of them were serendipitously found by desperate clini- cians, without an understanding of the mechanisms of how pruritus emerges and how it can be influenced [6-9]. However, with time, some of these observations were confirmed in controlled clinical trials and enabled scientists to arrange the puzzle, resulting in rational choices and improved efficacy of treatment.

At the moment we have at our disposal a couple of new concepts and promising treatments. They will be discussed in this article. I shall refrain, however, from repeating what was written about topical treatment of pruritus by dermatologists.

\section{How does pruritus originate in cancer?}

In 1965 Cormia [10] portrayed more than 20 cases of pruritus related to malignancies. It was an unparalleled phenomenological description of this clinical entity. For the more recent description of this phenomenon, supported by decades of observations, I refer the reader to the article by Weisshaar et al. [11]. Cormia,

\footnotetext{
Address for correspondence:

Zbigniew Żylicz

Faculty of Medicine, University of Rzeszów, Rzeszów

e-mail: bezyna55@gmail.com
} 
however, suggested that pruritus is "a kind of allergy to the tumour" [12]. Fifty years later we can confirm that pruritus, as well as many other cancer-induced symptoms, are of immunological nature.

In cancer different types of pruritus are encountered. Sometimes these types occur concomitantly. The most important is chronic inflammatory type, in which inflammation may occur both in the skin and central nervous system (as neuroinflammation) $[2,4$, 13]. Another type is neuropathic pruritus in which the impulses are perpetuated in the central nervous system and become independent of the inflammatory impulses from the periphery. Both types of pruritus can be paraneoplastic in nature [1]. In cancer-related pruritus there is little space for the histamine release from the mast cells because this mechanism is seen practically only in urticaria [14] and in mastocytosis [15]. Hence, antihistamines are usually ineffective.

The bacteria, fungi, and viruses from our microbiome, whether friend or foe, communicate with our brain, stimulating it to develop [16] but also fight the infections [17]. The signals, usually in the form of lipopolysaccharides (LPS), endotoxins derived from Gram-negative bacteria, are sent from the gut to the microglia in the brain. On the surface of the microglia cells, as well as on the surface of many other macrophages, this microbial-derived material reacts with the diverse family of pattern recognition receptors, including Toll-like receptors (TLRs) [18]. These receptors initiate diverse inflammatory cascades in which many cytokines are involved [18]. This usually results in an antimicrobial effect and health restoration. However, if the signal is persistent and the infection is insuperable, cytokines may initiate a state of permanent neuroinflammation [19].

The mechanism of microbe-initiated neuroinflammation had been found to be pathognomonic in many (until now, poorly understood) neurological diseases [20-24]. Increased production of interferon-alpha (IF- $\alpha$ ) after stimulation of TLRs with LPS had been found to be pathognomonic for psychological depression [25]. Of interest, depression induced by IF- $\alpha$ treatment was amenable by paroxetine, a selective serotonin reuptake inhibitor (SSRI) [26].

\section{The role of selective serotonin reuptake inhibitors}

One patient with lung cancer and severe intractable paraneoplastic itch tried to commit suicide and was treated for alleged depression with paroxetine, which cured his pruritus [6]. A similar observation was made in cholestatic pruritus in primary biliary cirrhosis after treatment with sertraline [7]. These observations resulted in controlled clinical trials with paroxetine in mainly cancer-related pruritus [27] and in cholestatic pruritus with sertraline [28]. The results were supported later by a more robust, semi-controlled trial of paroxetine and fluvoxamine used in mainly dermatological pruritus [29].

For a long time, the mechanism of the beneficial effects of SSRI in pruritus remained obscure. However, SSRIs (including paroxetine) were found to interact with TLR inducing a powerful anti-inflammatory effect in animal models [30, 31]. Additionally, antidepressants like paroxetine had been found to be inhibitory to $\mathrm{P} 2 \mathrm{X} 4$ purinergic receptors, another actor in the induction of neurogenic inflammation [32]. In animal studies, mainly TLR-7 [33] but also TLR-3 and TLR-4 activation were implicated in the initiation of pruritic reaction [34].

Where does this knowledge bring us now? For some SSRIs, clinical evidence is limited to paroxetine, sertraline, and fluvoxamine, which appear to be powerful inhibitors of pruritus [35]. It seems that SSRIs possess a powerful inhibitory effect on neurogenic inflammation. This line of evidence is far from complete. It appears that different antidepressants are able to evoke different responses from the microglial Toll-like receptors, thus making meaningful a switch from one drug to another. Also, SSRIs appear to be broad-spectrum antipruritics, effective in different types of pruritus.

\section{Itch transmission as a target of antipruritic therapy}

Itch impulses usually initiates in the skin or mucous membranes and are transported to the spinal cord by a sophisticated network consisting mainly of C-fibres to the spinal cord and brain [36]. On its way from the periphery to the central nervous system, the itch can be inhibited on every level.

In the pruritus seen in T-cell cutaneous lymphoma, interleukin-31 appears to play a leading role [37]. There are no clinically proven IL-31 inhibitors as yet. Anti-inflammatory effects of topical treatments used by dermatologists play an important role, albeit only supportive, in treatment of cancer-related pruritus. Most probably prostaglandins and histamine only potentiate pruritus but do not initiate it [38].

\section{Aprepitant and serlopitant}

Other viable targets for the treatment are the NK1 receptors binding substance $P$ in the synapses of the spinal cord. Substance $P$ appears to be a key mediator of pruritus [39]. Pruritic skin shows increased expression of NK1 receptors responding to substance P [40]. 
Again there has been an observation that aprepitant, an NK1 antagonist, used to treat nausea and vomiting appears to be effective in three patients with severe pruritus complicating cutaneous lymphoma [41]. This triggered series of case reports, especially in pruritus induced by anticancer treatment [42-44], but also in cutaneous lymphomas and solid tumours [45-49]. Other types of pruritus were also responsive to aprepitant [8]. Formal clinical trials were performed recently with an congener serlopitant, specially developed as an antipruritic drug [50,51]. These trials showed that serlopitant induced statistically significant reduction of pruritis in chronic, but not necessarily cancer-related pruritus.

\section{Gabapentin and pregabalin}

Gabapentin and pregabalin (gabapentinoids) were originally developed as antiepileptics because they are analogues of gamma-aminobutyric acid. However, it appeared later that their main mechanism of action is related to inhibition of the alpha-2-delta $(\alpha-2-\delta)$ subunit of voltage-dependent calcium channels in the dorsal root ganglion and the spinal cord dorsal horn. As such, these drugs increase the threshold for propagation of pruritic stimuli $[52,53]$. It appears that gabapentinoids modulate the release of substance $P$ in the spinal cord, but only in the case of significant inflammation-induced sensitisation of the spinal cord [54].

Gabapentinoids are successfully used in the treatment of neuropathic pain [55] and, by analogy, in the treatment of neuropathic pruritus [35]. However, these drugs appeared especially effective in uremic pruritus [56] and burns-associated pruritus [57]. In contrast, gabapentin appeared ineffective in the treatment of cholestasis-associated pruritus [58]. In summary, gabapentinoids are potentially useful in cancer-related pruritus, especially when neuropathic pruritus is probable.

\section{Opioids and opioid antagonists}

Opioids are known to induce pruritus. MOR agonists are thought to induce both analgesia and pruritus [59]. KOR agonists induce analgesia but inhibit pruritus [59]. Pain, by the activation of interneurons, inhibits propagation of pruritus [36].

\section{Nalfurafine}

The KOR agonist nalfurafine was introduced first in Japan for the treatment of uraemic pruritus, but recently it has appeared to be effective also in cholestatic pruritus $[60,61]$. Very few adverse effects will almost certainly prompt other studies when the drug becomes available on the world market. Nalfurafine has not been tested in any form of cancer-related pruritus.

\section{Naloxone}

Naloxone, and its orally active congener naltrexone, well-known opioid antagonists, were found to be effective in cholestatic pruritus [62]. However, antagonists induce unpleasant withdrawal syndrome even in patients who have not taken any opioids [63]. In the context of cancer-related pruritus there was a reasonable fear that opioid antagonists would unmask analgesia. For decades we were taught that naloxone's efficacy was related to antagonism of opioid receptors. However, naloxone and naltrexone binds also to Toll-like (especially TLR-4) receptors and can have influence on Toll-like-related pronociceptive signalling and thus pruritus [64]. Toll-like receptors are not stereo selective, thus application of (+)-naloxone would block Toll-like receptors and have effect reinforcing effects of opioids [64, 65]. This strategy seems to be promising in neuropathic pain $[66,67]$ and should also be tested in pruritus. It could be that the antipruritic effects of naloxone and naltrexone observed by the group of Bergasa et al. [68] are based on Toll-like antagonism.

\section{Buprenorphine}

Buprenorphine is a partial agonist of MOR and antagonist of KOR [69]. It was suggested that high affinity of buprenorphine to MOR would prevent binding of alleged pruritogenic opioid peptides. Nothing like this was ever proven, but buprenorphine as an antipruritic has been tested in a controlled clinical trial with a sublingual preparation [70]. Only five patients were subjected to treatment. Two patients responded well, but three had intolerable adverse effects. The trial was terminated. The concept, however, has been extended to transdermal buprenorphine, and several cases of beneficial effects of buprenorphine in cancer-related pruritus have been reported [71-73]. No further clinical trials have been attempted.

Again, besides the effects of buprenorphine on opioid receptors, buprenorphine also reacts with Toll-like receptors and it activates TLR-4 much less than, for example, morphine-3-glucuronide or control medium with bacterial LPS [64]. In summary, this effect remains unproven but very interesting because buprenorphine does not induce withdrawal and does not revert analgesia like naloxone.

\section{Conclusions}

Pruritus in cancer is a highly heterogenous phenomenon. The spectrum starts from the cholestatic, paraneoplastic, and neuropathic itch and ends with (cancer) therapy-related pruritus (omitted in this review). It is a rare but traditionally therapy-resistant 
symptom. Recently, marked progress has been seen in the field of anti-pruritic therapy. Some new drugs have already been tested in controlled clinical trials, although the data are still scant. The most important concept is the central and peripheral neuroinflammation related to Toll-like receptors. Most drugs that proved to be effective in pruritus in cancer are also effective on Toll-like receptors, suggesting that these receptors should be the main target for the development of new drugs. Unfortunately the development of new SSRIs is stagnated because of a reported increased suicide rate in young patients using these drugs to combat depression [74, 75, 76]. It is, however, conceivable that new, centrally acting anti-inflammatory drugs will be developed in future, both for the treatment of pruritus as well as other neurodegenerative diseases.

Other drugs efficacious in the treatment of pruritus in cancer act on the transport of impulses in the spinal cord and brain. These drugs, like gabapentin and pregabalin, have been known for some time but did not change much in our clinical management of pruritus. On the other hand, aprepitant and its new, purportedly developed congener serlopitant is promising, also in cancer.

Yet another group of drugs is related to opioids and opioids antagonists. Here, studies with (+)-naloxone and $(+)$-naltrexone are urgently needed. Recently introduced in uremic pruritus, nalfurafine should also be tested in cancer-related pruritus. These studies are lagging behind because pruritus in cancer is complex and relatively rare. In the treatment of cancer-related pruritus there is little or no space for antihistamines.

\section{Conflict of interests}

Author declare no conflict of interest.

\section{Funding}

This study has no funding.

\section{References}

1. Rowe B, Yosipovitch G. Malignancy-associated pruritus. Eur J Pain. 2016; 20(1): 19-23, doi: 10.1002/ejp.760, indexed in Pubmed: 26416212.

2. Lidstone V, Thorns A. Pruritus in cancer patients. Cancer Treat Rev. 2001; 27(5): 305-312, doi: 10.1053/ctrv.2001.0231, indexed in Pubmed: 11871867.

3. Simone DA, Ngeow JY, Whitehouse J, et al. The magnitude and duration of itch produced by intracutaneous injections of histamine. Somatosens Res. 1987; 5(2): 81-92, doi: 10.3109/07367228709144620, indexed in Pubmed: 3423533.

4. Twycross R, Greaves MW, Handwerker $\mathrm{H}$, et al. Itch: scratching more than the surface. QJM. 2003; 96(1): 7-26, doi: 10.1093/qjmed/hcg002, indexed in Pubmed: 12509645.

5. Church MK, Church DS. Pharmacology of antihistamines. Indian J Dermatol. 2013; 58: 219-24.

6. Zylicz Z, Smits C, Krajnik M. Paroxetine for pruritus in advanced cancer. J Pain Symptom Manage. 1998; 16(2):
121-124, doi: 10.1016/s0885-3924(98)00048-7, indexed in Pubmed: 9737103.

7. Browning J, Combes B, Mayo MJ. Long-term efficacy of sertraline as a treatment for cholestatic pruritus in patients with primary biliary cirrhosis. Am J Gastroenterol. 2003; 98(12): 2736-2741, doi: 10.1111/j.1572-0241.2003.08662.x, indexed in Pubmed: 14687826.

8. Ständer S, Siepmann D, Herrgott I, et al. Targeting the neurokinin receptor 1 with aprepitant: a novel antipruritic strategy. PLoS One. 2010; 5(6): e10968, doi: 10.1371/journal.pone.0010968, indexed in Pubmed: 20532044.

9. Yesudian PD, Wilson NJE. Efficacy of gabapentin in the management of pruritus of unknown origin. Arch Dermatol. 2005; 141(12): 1507-1509, doi: 10.1001/archderm.141.12.1507, indexed in Pubmed: 16365250.

10. Cormia FE. Pruritus, an uncommon but important symptom of systemic carcinoma. Arch Dermatol. 1965; 92(1): 36-39, indexed in Pubmed: 11850949.

11. Weisshaar E, Weiss M, Mettang $T$, et al. Special Interest Group of the International Forum on the Study of Itch. Paraneoplastic itch: an expert position statement from the Special Interest Group (SIG) of the International Forum on the Study of Itch (IFSI). Acta Derm Venereol. 2015; 95(3): 261-265, doi: 10.2340/00015555-1959, indexed in Pubmed: 25179683.

12. Cormia FE, Domonkos AN. Cutaneous Reactions to Internal Malignancy. Med Clin North Am. 1965; 49: 655-680, doi: 10.1016/s0025-7125(16)33313-2, indexed in Pubmed: 14277567.

13. Krajnik M, Zylicz Z. Pruritus accompanying solid tumors. In: Zylicz Z, Twycross R, Jones EA. ed. Pruritus in advanced disease. 1st ed. Oxford University Press, Oxford 2004: 97-106.

14. Zuberbier T, Maurer M. Urticaria: current opinions about etiology, diagnosis and therapy. Acta Derm Venereol. 2007; 87(3): 196-205, doi: 10.2340/00015555-0240, indexed in Pubmed: 17533484.

15. Lange $\mathrm{M}$, Gleń J, Zabłotna $\mathrm{M}$, et al. Interleukin-31 Polymorphisms and Serum IL-31 Level in Patients with Mastocytosis: Correlation with Clinical Presen-tation and Pruritus. Acta Derm Venereol. 2017; 97(1): 47-53, doi: 10.2340/00015555-2474, indexed in Pubmed: 27276346.

16. Sampson TR, Mazmanian SK. Control of brain development, function, and behavior by the microbiome. Cell Host Microbe. 2015; 17(5): 565-576, doi: 10.1016/j. chom.2015.04.011, indexed in Pubmed: 25974299.

17. Erny $D$, Hrabě de Angelis AL, Prinz M. Communicating systems in the body: how microbiota and microglia cooperate. Immunology. 2017; 150(1): 7-15, doi: 10.1111/imm.12645, indexed in Pubmed: 27392533.

18. Moresco EM, LaVine D, Beutler B. Toll-like receptors. Curr Biol. 2011; 21(13): R488-R493, doi: 10.1016/j. cub.2011.05.039, indexed in Pubmed: 21741580.

19. Gárate I, Garcia-Bueno B, Madrigal JL, et al. Stress-induced neuroinflammation: role of the Toll-like receptor-4 pathway. Biol Psychiatry. 2013; 73(1): 32-43, doi: 10.1016/j. biopsych.2012.07.005, indexed in Pubmed: 22906518.

20. Sanchez-Guajardo V, Tentillier N, Romero-Ramos M. The relation between $\alpha$-synuclein and microglia in Parkinson's disease: Recent developments. Neuroscience. 2015; 302: 47-58, doi: 10.1016/j.neuroscience.2015.02.008, indexed in Pubmed: 25684748.

21. Fuxe KG, Tarakanov AO, Goncharova $L B$, et al. A new road to neuroinflammation in Parkinson's disease? Brain Res Rev. 2008; 58(2): 453-458, doi: 10.1016/j.brainresrev.2008.04.003, indexed in Pubmed: 18457883.

22. Gooshe M, Abdolghaffari AH, Gambuzza ME, et al. The role of Toll-like receptors in multiple sclerosis and possible targeting for therapeutic purposes. Rev Neurosci. 2014; 
25(5): 713-739, doi: 10.1515/revneuro-2014-0026, indexed in Pubmed: 24914714.

23. Doorn KJ, Moors T, Drukarch B, et al. Microglial phenotypes and toll-like receptor 2 in the substantia nigra and hippocampus of incidental Lewy body disease cases and Parkinson's disease patients. Acta Neuropathol Commun. 2014; 2: 90, doi: 10.1186/s40478-014-0090-1, indexed in Pubmed: 25099483.

24. Nyati KK, Prasad KN. Role of cytokines and Toll-like receptors in the immunopathogenesis of Guillain-Barré syndrome. Mediators Inflamm. 2014; 2014: 758639, doi: 10.1155/2014/758639, indexed in Pubmed: 25614713.

25. Raison CL, Capuron L, Miller AH. Cytokines sing the blues: inflammation and the pathogenesis of depression. Trends Immunol. 2006; 27(1): 24-31, doi: 10.1016/j. it.2005.11.006, indexed in Pubmed: 16316783.

26. Capuron L, Gumnick JF, Musselman DL, et al. Neurobehavioral effects of interferon-alpha in cancer patients: phenomenology and paroxetine responsiveness of symptom dimensions. Neuropsychopharmacology. 2002; 26(5): 643-652, doi: 10.1016/50893-133X(01)00407-9, indexed in Pubmed: 11927189.

27. Zylicz Z, Krajnik M, Sorge AA, et al. Paroxetine in the treatment of severe non-dermatological pruritus: a randomized, controlled trial. J Pain Symptom Manage. 2003; 26(6): 1105-1112, doi: 10.1016/j.jpainsymman.2003.05.004, indexed in Pubmed: 14654262.

28. Mayo MJ, Handem I, Saldana S, et al. Sertraline as a first-line treatment for cholestatic pruritus. Hepatology. 2007; 45(3): 666-674, doi: 10.1002/hep.21553, indexed in Pubmed: 17326161.

29. Ständer S, Böckenholt B, Schürmeyer-Horst F, et al. Treatment of chronic pruritus with the selective serotonin re-uptake inhibitors paroxetine and fluvoxamine: results of an open-labelled, two-arm proof-of-concept study. Acta Derm Venereol. 2009; 89(1): 45-51, doi: 10.2340/00015555-0553, indexed in Pubmed: 19197541.

30. Liu RP, Zou M, Wang JY, et al. Paroxetine ameliorates lipopolysaccharide-induced microglia activation via differential regulation of MAPK signaling. J Neuroinflammation. 2014; 11: 47, doi: 10.1186/1742-2094-11-47, indexed in Pubmed: 24618100.

31. Durairaj H, Steury MD, Parameswaran N. Paroxetine differentially modulates LPS-induced TNF and IL- 6 production in mouse macrophages. Int Immunopharmacol. 2015; 25(2): 485-492, doi: 10.1016/j.intimp.2015.02.029, indexed in Pubmed: 25744603.

32. Nagata K, Imai T, Yamashita T, et al. Antidepressants inhibit P2X4 receptor function: a possible involvement in neuropathic pain relief. Mol Pain. 2009; 5: 20, doi: 10.1186/1744-8069-5-20, indexed in Pubmed: 19389225.

33. Liu T, Xu ZZ, Park CK, et al. Toll-like receptor 7 mediates pruritus. Nat Neurosci. 2010; 13(12): 1460-1462, doi: 10.1038/nn.2683, indexed in Pubmed: 21037581.

34. Taves S, Ji RR. Itch control by Toll-like receptors. Handb Exp Pharmacol. 2015; 226: 135-150, doi: 10.1007/978-3-66244605-8 7, indexed in Pubmed: 25861777.

35. Kaur R, Sinha VR. Antidepressants as antipruritic agents: A review. Eur Neuropsychopharmacol. 2018; 28(3): 341352, doi: 10.1016/j.euroneuro.2018.01.007, indexed in Pubmed: 29456150.

36. Schmelz M. Itch and pain. Neurosci Biobehav Rev. 2010; 34(2): 171-176, doi: 10.1016/j.neubiorev.2008.12.004, indexed in Pubmed: 19146873.

37. Nattkemper LA, Martinez-Escala ME, Gelman AB, et al. Cutaneous T-cell Lymphoma and Pruritus: The Expression of IL-31 and its Receptors in the Skin. Acta Derm Venereol. 2016; 96(7): 894-898, doi: 10.2340/00015555-2417, indexed in Pubmed: 27001482.
38. Greaves MW, McDonald-Gibson W. Itch: role of prostaglandins. Br Med J. 1973; 3(5881): 608-609, doi: 10.1136/bmj.3.5881.608, indexed in Pubmed: 4755182.

39. Wallengren J. Neuroanatomy and neurophysiology of itch. Dermatol Ther. 2005; 18(4): 292-303, doi: 10.1111/j.1529-8019.2005.00041.x, indexed in Pubmed: 16297000.

40. Chang SE, Han SS, Jung HJ, et al. Neuropeptides and their receptors in psoriatic skin in relation to pruritus. $\mathrm{Br}$ J Dermatol. 2007; 156(6): 1272-1277, doi: 10.1111/j. 1365-2133.2007.07935.x, indexed in Pubmed: 17535226.

41. Duval A, Dubertret L. Aprepitant as an antipruritic agent? N Engl J Med. 2009; 361(14): 1415-1416, doi: 10.1056/NEJMc0906670, indexed in Pubmed: 19797294.

42. Vincenzi B, Tonini G, Santini D. Aprepitant for erlotinib-induced pruritus. N Engl J Med. 2010; 363(4): 397-398, doi: 10.1056/NEJMc1003937, indexed in Pubmed: 20660413.

43. Santini D, Vincenzi B, Guida FM, et al. Aprepitant for management of severe pruritus related to biological cancer treatments: a pilot study. Lancet Oncol. 2012; 13(10): 1020-1024, doi: 10.1016/S1470-2045(12)70373-X, indexed in Pubmed: 22995650.

44. Ito J, Fujimoto D, Nakamura A, et al. Aprepitant for refractory nivolumab-induced pruritus. Lung Cancer. 2017; 109: 58-61, doi: 10.1016/j.lungcan.2017.04.020, indexed in Pubmed: 28577951.

45. Vincenzi B, Fratto ME, Santini D, et al. Aprepitant against pruritus in patients with solid tumours. Support Care Cancer. 2010; 18(9): 1229-1230, doi: 10.1007/s00520010-0895-9, indexed in Pubmed: 20544226.

46. Torres T, Fernandes I, Selores M, et al. Aprepitant: Evidence of its effectiveness in patients with refractory pruritus continues. J Am Acad Dermatol. 2012; 66(1): e14-e15, doi: 10.1016/j.jaad.2011.01.016, indexed in Pubmed: 22177649.

47. Borja-Consigliere HA, López-Pestaña A, Vidal-Manceñido MJ, et al. Aprepitant in the treatment of refractory pruritus secondary to cutaneous T-cell lymphoma. Actas Dermosifiliogr. 2014; 105(7): 716-718, doi: 10.1016/j. ad.2013.07.007, indexed in Pubmed: 24139470.

48. Jiménez Gallo $D$, Albarrán Planelles $C$, Linares Barrios $M$, et al. Treatment of pruritus in early-stage hypopigmented mycosis fungoides with aprepitant. Dermatol Ther. 2014; 27(3): 178-182, doi: 10.1111/dth.12113, indexed in Pubmed: 24517320 .

49. Maroñas-Jiménez L, Estrach T, Gallardo F, et al. Aprepitant improves refractory pruritus in primary cutaneous T-cell lymphomas: experience of the Spanish Working Group on Cutaneous Lymphomas. Br J Dermatol. 2018; 178(4): e273-e274, doi: 10.1111/bjd.16128, indexed in Pubmed: 29150837.

50. Yosipovitch G, Ständer S, Kerby MB, et al. Serlopitant for the treatment of chronic pruritus: Results of a randomized, multicenter, placebo-controlled phase 2 clinical trial. J Am Acad Dermatol. 2018; 78(5): 882-891.e10, doi: 10.1016/j. jaad.2018.02.030, indexed in Pubmed: 29462657.

51. Ständer S, Kwon P, Hirman J, et al. TCP-102 Study Group. Serlopitant reduced pruritus in patients with prurigo nodularis in a phase 2, randomized, placebo-controlled trial. J Am Acad Dermatol. 2019; 80(5): 1395-1402, doi: 10.1016/j.jaad.2019.01.052, indexed in Pubmed: 30894279.

52. Li Z, Taylor CP, Weber M, et al. Pregabalin is a potent and selective ligand for $\alpha(2) \delta-1$ and $\alpha(2) \delta-2$ calcium channel subunits. Eur J Pharmacol. 2011; 667(1-3): 80-90, doi: 10.1016/j.ejphar.2011.05.054, indexed in Pubmed: 21651903.

53. Quintero JE, Dooley DJ, Pomerleau F, et al. Amperometric measurement of glutamate release modulation by gaba- 
pentin and pregabalin in rat neocortical slices: role of voltage-sensitive $\mathrm{Ca} 2+\alpha 2 \delta-1$ subunit. J Pharmacol Exp Ther. 2011; 338(1): 240-245, doi: 10.1124/jpet.110.178384, indexed in Pubmed: 21464332.

54. Fehrenbacher JC, Taylor CP, Vasko MR. Pregabalin and gabapentin reduce release of substance $P$ and CGRP from rat spinal tissues only after inflammation or activation of protein kinase C. Pain. 2003; 105(1-2): 133-141, doi: 10.1016/s0304-3959(03)00173-8, indexed in Pubmed: 14499429.

55. Dworkin RH, O'Connor AB, Backonja M, et al. Pharmacologic management of neuropathic pain: evidence-based recommendations. Pain. 2007; 132(3): 237-251, doi: 10.1016/j. pain.2007.08.033, indexed in Pubmed: 17920770.

56. Simonsen E, Komenda P, Lerner B, et al. Treatment of Uremic Pruritus: A Systematic Review. Am J Kidney Dis. 2017; 70(5): 638-655, doi: 10.1053/j.ajkd.2017.05.018, indexed in Pubmed: 28720208.

57. Kaul I, Amin A, Rosenberg M, et al. Use of gabapentin and pregabalin for pruritus and neuropathic pain associated with major burn injury: A retrospective chart review. Burns. 2018; 44(2): 414-422, doi: 10.1016/j. burns.2017.07.018, indexed in Pubmed: 28822592.

58. Bergasa NV, McGee M, Ginsburg IH, et al. Gabapentin in patients with the pruritus of cholestasis: a double-blind, randomized, placebo-controlled trial. Hepatology. 2006; 44(5): 1317-1323, doi: 10.1002/hep.21370, indexed in Pubmed: 17058231.

59. Ständer S, Schmelz M. Chronic itch and pain--similarities and differences. Eur J Pain. 2006; 10(5): 473-478, doi: 10.1016/j. ejpain.2006.03.005, indexed in Pubmed: 16678456.

60. Inui S. Nalfurafine hydrochloride to treat pruritus: a review. Clin Cosmet Investig Dermatol. 2015; 8: 249-255, doi: 10.2147/CCID.S55942, indexed in Pubmed: 26005355.

61. Akuta N, Kumada H, Fujiyama S, et al. Recurrence rates of pruritus after the stop of nalfurafine hydrochloride in chronic liver disease: Preliminary prospective confirmatory trial. Hepatol Res. 2018; 48(10): 810-813, doi: 10.1111/hepr.13075, indexed in Pubmed: 29601141.

62. Bergasa NV. The pruritus of cholestasis: From bile acids to opiate agonists: Relevant after all these years. Med Hypotheses. 2018; 110: 86-89, doi: 10.1016/j.mehy.2017.11.002, indexed in Pubmed: 29317077.

63. Jones EA, Neuberger J, Bergasa NV. Opiate antagonist therapy for the pruritus of cholestasis: the avoidance of opioid withdrawal-like reactions. QJM. 2002; 95(8): 547-552, doi: 10.1093/qjmed/95.8.547, indexed in Pubmed: 12145394.

64. Hutchinson MR, Zhang Y, Shridhar M, et al. Evidence that opioids may have toll-like receptor 4 and MD-2 effects. Brain Behav Immun. 2010; 24(1): 83-95, doi: 10.1016/j. bbi.2009.08.004, indexed in Pubmed: 19679181.
65. Jurga AM, Rojewska E, Piotrowska A, et al. Blockade of Toll-Like Receptors (TLR2, TLR4) Attenuates Pain and Potentiates Buprenorphine Analgesia in a Rat Neuropathic Pain Model. Neural Plast. 2016; 2016: 5238730, doi: 10.1155/2016/5238730, indexed in Pubmed: 26962463.

66. Lewis SS, Loram LC, Hutchinson MR, et al. (+)-naloxone, an opioid-inactive toll-like receptor 4 signaling inhibitor, reverses multiple models of chronic neuropathic pain in rats. J Pain. 2012; 13(5): 498-506, doi: 10.1016/j.jpain.2012.02.005, indexed in Pubmed: 22520687.

67. Wang $X$, Zhang $Y$, Peng $Y$, et al. Pharmacological characterization of the opioid inactive isomers $(+)$-naltrexone and (+)-naloxone as antagonists of toll-like receptor 4 . Br J Pharmacol. 2016; 173(5): 856-869, doi: 10.1111/bph.13394, indexed in Pubmed: 26603732.

68. Bergasa NV. The pruritus of cholestasis: facts. Hepatology. 2015; 61(6): 2114, doi: 10.1002/hep.27582, indexed in Pubmed: 25345776.

69. Pergolizzi J, Aloisi AM, Dahan A, et al. Current knowledge of buprenorphine and its unique pharmacological profile. Pain Pract. 2010; 10(5): 428-450, doi: 10.1111/j. 1533-2500.2010.00378.x, indexed in Pubmed: 20492579.

70. Juby LD, Wong VS, Losowsky MS. Buprenorphine and hepatic pruritus. Br J Clin Pract. 1994; 48(6): 331, indexed in Pubmed: 7848799.

71. Reddy L, Krajnik M, Zylicz Z. Transdermal buprenorphine may be effective in the treatment of pruritus in primary biliary cirrhosis. J Pain Symptom Manage. 2007; 34(5): 455-456, doi: 10.1016/j.jpainsymman.2007.08.001, indexed in Pubmed: 17900853.

72. Krajnik M. Adamczyk, A., Zylicz, Z. Transdermal buprenorphine ameliorated pruritus complicating advanced hepatocellular cancer. Adv Palliative Medicine. 2007; 6: 83-86.

73. Zylicz Z, Stork N, Krajnik M. Severe pruritus of cholestasis in disseminated cancer: developing a rational treatment strategy. A case report. J Pain Symptom Manage. 2005; 29(1): 100-103, doi: 10.1016/j.jpainsymman.2004.04.009, indexed in Pubmed: 15652443.

74. Aursnes I, Tvete IF, Gaasemyr J, et al. Suicide attempts in clinical trials with paroxetine randomised against placebo. BMC Med. 2005; 3: 14, doi: 10.1186/1741-7015-3-14, indexed in Pubmed: 16115311.

75. Aursnes I, Tvete IF, Gaasemyr J, et al. Even more suicide attempts in clinical trials with paroxetine randomised against placebo. BMC Psychiatry. 2006; 6: 55, doi: 10.1186/1471244X-6-55, indexed in Pubmed: 17129393.

76. Shah A, Bhat R. Fluoxetine and sertraline may be associated with lower risk of suicide death than paroxetine in adults with depression. Evid Based Ment Health. 2012; 15(4): 98 , doi: 10.1136/ebmental-2012-100875, indexed in Pubmed: 22888103. 


\section{Zbigniew Żylicz}

\section{Świąd u chorych na nowotwory - obecny stan wiedzy i leczenie}

Artykuł jest tłumaczeniem pracy: Żylicz Z. Pruritus in Cancer. Current Understanding and Treatment. Palliat. Med. Pract. 2020 tom 14, nr 1: 16-21.

Należy cytować wersję pierwotną.

Piśmiennictwo znajduje się na stronach 19-21.

\section{Streszczenie}

Świąd w przebiegu chorób nowotworowych jest bardzo różnorodny. W ostatnich dwóch dekadach zrozumienie tego objawu znacznie się poprawiło, co zaowocowało powstaniem nowych sposobów leczenia. Nowsze metody leczenia zostaną wdrożone już niedługo. Najważniejszym mechanizmem tłumaczącym świąd w przebiegu chorób nowotworowych to neuroinflammacja, zarówno w skórze, jak i w rdzeniu kręgowym i mózgu, gdzie receptory Toll-like odgrywają najważniejszą rolę. Czynność tych receptorów można modyfikować istniejącym lekami, jak opioidy, antagoniści opioidowi, a także leki hamujące wychwyt zwrotny serotoniny i inne. Innym sposobem działania przeciwświądowego jest zahamowanie przewodnictwa świądowego w skórze, rdzeniu kręgowym i mózgu poprzez zahamowanie receptorów NK1 przez aprepitant i serlopitant, a także przez gabapentynę i pregabalinę. Żaden z mechanizmów powstawania świądu nie jest zależny od uwalniania histaminy, dlatego nie powinno się w tym celu używać leków przeciwhistaminowych.

Palliat Med Pract 2020; 14, 1: 22-25

Słowa kluczowe: świąd, swędzenie, nowotwór, zjawisko paraneoplastyczne, inhibitory wychwytu zwrotnego serotoniny, paroksetyna, sertralina, gabapentyna, pregabalina, aprepitant

\section{Wstęp}

Świąd towarzyszący złośliwym chorobom nowotworowym jest rzadki i różnorodny [1, 2]. Może być przewlekły i stanowić poważny problem kliniczny. Nie tak dawno temu rozumienie świądu ograniczało się do tego, że histamina wstrzykiwana podskórnie powodowała intensywne swędzenie i zaostrzenie [3]. Mechanizm ten, jedyny wówczas znany, oparty na uwalnianiu histaminy z mastocytów, okazał się całkowicie nieistotny w leczeniu ciężkiego świądu w chorobach nowotworowych, a teraz wiadomo, że istnieją niehistaminowe drogi swędzenia i wymagają innego podejścia [4]. Mimo to wielu klinicystów nadal przepisuje leki przeciwhistaminowe na świąd związany z nowotworami. Czasami są one pomoc- ne, ale wydaje się, że jest to bardziej związane $z$ antycholinergicznym i uspokajającym działaniem starszych leków przeciwhistaminowych [5].

W ciągu ostatnich 25 lat opracowano kilka nowych terapii świądu związanego z nowotworami. Większość z nich została odkryta przez zdesperowanych klinicystów bez zrozumienia mechanizmów powstawania świądu i jaki mogą one mieć na niego wpływ [6-9]. Jednak z czasem niektóre $z$ tych obserwacji zostały potwierdzone w kontrolowanych badaniach klinicznych i umożliwiły naukowcom ułożenie układanki, co zaowocowało racjonalnymi wyborami i poprawą skuteczności leczenia.

W chwili obecnej mamy do dyspozycji kilka nowych koncepcji i obiecujących metod leczenia. Zostaną one omówione w niniejszym artykule. Jednak bez powie-

Adres do korespondencji:

Zbigniew Żylicz

Wydział Medyczny, Uniwersytet Rzeszowski, Rzeszów

e-mail: bezyna55@gmail.com 
lania tego, co zostało już napisane o miejscowym leczeniu świądu przez dermatologów.

\section{Jaki jest patomechanizm świądu u chorych na nowotwory?}

W 1965 roku w badaniach autorstwa Cormii [10] przedstawiono ponad 20 przypadków świądu związanego z nowotworami złośliwymi. Był to niezrównany opis fenomenologiczny tej jednostki klinicznej. W celu zapoznania się z nowszym opisem tego zjawiska, popartego wieloletnimi obserwacjami, autor pracy odsyła czytelnika do artykułu Weisshaar i wsp. [11]. Cormia sugeruje jednak, że świąd jest „rodzajem alergii na guza" [12]. Pięćdziesiąt lat później można potwierdzić, że świąd, podobnie jak wiele innych objawów wywołanych przez raka, ma charakter immunologiczny.

W chorobach nowotworowych występują różne rodzaje świądu. Czasami występują one równocześnie. Najważniejszy jest przewlekły typ zapalenia, gdzie zapalenie może wystąpić zarówno w skórze, jak i w ośrodkowym układzie nerwowym (jako neurozapalenie) $[2,4,13]$. Innym typem jest świąd neuropatyczny, w którym impulsy są utrwalane $w$ ośrodkowym układzie nerwowym i uniezależniają się od impulsów zapalnych z obwodu. Oba rodzaje świądu mogą mieć charakter paraneoplastyczny [1]. W przypadku świądu związanego $z$ nowotworami istnieje niewiele miejsca na uwolnienie histaminy $z$ mastocytów, ponieważ mechanizm ten jest widoczny praktycznie tylko w pokrzywce [14] i mastocytozie [15]. Dlatego też leki przeciwhistaminowe są zazwyczaj nieskuteczne.

Bakterie, grzyby i wirusy z naszego mikrobiomu, czy to przyjazne, czy nie, komunikują się z mózgiem, stymulując go do rozwoju [16], ale także zwalczając infekcje [17]. Sygnały te, zazwyczaj w postaci endotoksyn lipopolisacharydowych (LPS, lipopolysaccharide) pochodzących od bakterii Gram-ujemnych, są wysyłane z jelita do mikrogleju w mózgu. Na powierzchni komórek mikrogleju, ale także na powierzchni wielu innych makrofagów ten materiał pochodzenia mikrobiologicznego reaguje $z$ różnorodną rodziną receptorów rozpoznawania wzorów, wśród nich z receptorami Toll-like (TLR, Toll-like receptor) [18]. Receptory te inicjują różnorodne kaskady zapalne, w których bierze udział wiele cytokin [18]. Zazwyczaj powoduje to efekt antybakteryjny i przywrócenie zdrowia. Jeżeli jednak sygnał jest trwały, a infekcja jest nie do zniesienia, cytokiny mogą zainicjować stan permanentnego neurozapalenia [19].

Mechanizm neurozapalenia inicjowanego przez mikroorganizmy uznaje się za patognomoniczny w wielu, do tej pory słabo poznanych chorobach neurologicznych [20-24]. Zwiększoną produkcję interferonu $\alpha$ po stymulacji TLR z LPS uznano za patognomoniczną dla depresji psychicznej [25]. Co ciekawe, depresja indukowana przez leczenie IFN- $\alpha$ była łagodzona przez paroksetynę, inhibitor wychwytu zwrotnego serotoniny (SSRI, selective serotonin reuptake inhibitor) [26].

\section{Rola selektywnych inhibitorów wychwytu zwrotnego serotoniny}

Jeden z pacjentów, który cierpiał na nowotwór płuca i silne paraneoplastyczne swędzenie, próbował popełnić samobójstwo i był leczony z powodu rzekomej depresji paroksetyną, która wyleczyła jego świąd [6]. Podobnej obserwacji dokonano w zakresie świądu cholestatycznego w pierwotnej marskości żótciowej wątroby po leczeniu sertraliną [7]. Obserwacje te zaowocowały kontrolowanymi badaniami klinicznymi z użyciem paroksetyny w przypadku świądu związanego głównie z nowotworami [27] oraz w przypadku świądu cholestatycznego z użyciem sertraliny [28]. Wyniki te zostały później poparte solidniejszym, na wpół kontrolowanym badaniem paroksetyny i fluwoksaminy stosowanych głównie $w$ dermatologicznym świądzie skóry [29].

Przez długi czas mechanizm korzystnych skutków SSRI w przypadku świądu pozostawał niejasny. Stwierdzono jednak, że między SSRI, a wśród nich paroksetyną, a receptorami Toll-like zachodzi interakcja, wywołując silne działanie przeciwzapalne w modelach zwierzęcych $[30,31]$. Dodatkowo stwierdzono, że leki przeciwdepresyjne, takie jak paroksetyna, hamują receptory purynowe P2X4, będące kolejnym czynnikiem indukującym zapalenie neurogenne [32]. W badaniach na zwierzętach aktywacja głównie TLR-7 [33], ale także TLR-3 i TLR-4 była związana z inicjacją reakcji świądu [34].

Dokąd ta wiedza nas zaprowadza? Niektóre SSRI, przy czym dowody kliniczne ograniczają się tylko do paroksetyny, sertraliny i fluwoksaminy, wydają się być silnymi inhibitorami świądu [35]. Przypuszcza się, że SSRI mają silny hamujący wpływ na zapalenie neurogenne. Ta linia dowodów jest daleka od kompletnej. Okazuje się, że różne leki przeciwdepresyjne są w stanie wywołać różne reakcje z Toll-like receptorów mikrogleju, co czyni sensownym zmianę jednego leku na inny. Ponadto, SSRI wydają się być środkami przeciwświądowymi o szerokim spektrum działania, skutecznymi w różnych rodzajach świądu.

\section{Transmisja świąqu jako cel leczenia}

Impulsy swędzenia zazwyczaj inicjują się w skórze lub błonach śluzowych i są transportowane do rdzenia 
kręgowego za pomocą skomplikowanej sieci składającej się głównie $z$ włókien $C$ do rdzenia kręgowego i mózgu [36]. Na drodze od obwodu do ośrodkowego układu nerwowego swędzenie może być zahamowane na każdym poziomie.

W świądzie widocznym w chłoniaku skórnym T-komórkowym interleukina-31 wydaje się odgrywać wiodącą rolę [37]. Nie ma jeszcze klinicznie potwierdzonych inhibitorów IL-31. Przeciwzapalne efekty leczenia miejscowego stosowanego przez dermatologów odgrywają ważną, choć tylko pomocniczą rolę w leczeniu świądu związanego z chorobami nowotworowymi. Prostaglandyny i histamina najprawdopodobniej tylko potęgują świąd, ale nie inicjują go [38].

\section{Aprepitant i serlopitant}

Kolejnym realnym celem leczenia są receptory NK1 wiążące substancję P w synapsach rdzenia kręgowego. Substancja $P$ wydaje się być kluczowym mediatorem świądu [39]. Skóra ze świądem wykazuje zwiększoną ekspresję receptorów NK1 reagujących na substancję $P$ [40]. Ponownie zaobserwowano, że aprepitant, antagonista NK1, stosowany w leczeniu nudności i wymiotów okazał się skuteczny u trzech pacjentów z ciężkim świądem komplikującym chłoniaka skórnego [41]. Wywołało to szereg zgłoszeń, szczególnie w świądzie wywołanym leczeniem przeciwnowotworowym [42-44], ale także w chłoniakach skórnych i guzach litych [45-49]. Inne rodzaje świądu również reagowały na aprepitant [8]. Ostatnio przeprowadzono formalne badanie kliniczne $z$ zastosowaniem kongeneru serlopitantu, opracowanego specjalnie jako lek przeciwświądowy [50, 51]. Badania te wykazały, że serlopitant powodował istotne statystycznie zmniejszenie świądu w przewlekłym, ale niekoniecznie związanym $z$ chorobą nowotworową świądzie.

\section{Gabapentyna i pregabalina}

Gabapentynę i pregabalinę (gabapentynoidy) opracowano pierwotnie jako leki przeciwpadaczkowe, jako że są analogami kwasu gamma-aminomasłowego. Jednak później okazało się, że ich główny mechanizm działania wiąże się $z$ inhibicją podjednostki alfa-2-delta sterowanych napięciem kanałów wapniowych w zwoju korzenia grzbietowego i rogu grzbietowym rdzenia kręgowego. Oznacza to, że leki te zwiększają próg propagacji bodźców świądowych $[52,53]$. Wydaje się, że gabapentynoidy modulują uwalnianie substancji $\mathrm{P}$ w rdzeniu kręgowym, ale tylko w przypadku znacznego uwrażliwienia rdzenia kręgowego wywołanego stanem zapalnym [54].

Gabapentynoidy są z powodzeniem stosowane w leczeniu bólu neuropatycznego [55] oraz, przez analogię, w leczeniu świądu neuropatycznego [35]. Jednakże leki z tej grupy okazały się szczególnie skuteczne w leczeniu świądu mocznicowego [56] i świądu związanego z oparzeniami [57]. Z drugiej strony, gabapentyna okazała się nieskuteczna w leczeniu świądu cholestatycznego [58]. Podsumowując, gabapentynoidy mogą potencjalnie być przydatne w leczeniu świądu związanego z chorobą nowotworową, szczególnie w przypadkach gdy prawdopodobny jest świąd neuropatyczny.

\section{Opioidy i antagoniści receptorów opioidowych}

Wiadomym jest, że opioidy wywołują świąd. Uważa się również, że agoniści receptorów opioidowych $\mu$ (MOR) mają działanie przeciwbólowe, ale jednocześnie wywołują świąd [59]. Z kolei agoniści receptorów opioidowych $\kappa(K O R)$ mają zarówno działanie przeciwbólowe, jak i hamują świąd [59]. Ból, poprzez aktywację interneuronów, hamuje propagację świądu [36].

\section{Nalfurafina}

Nalfurafinę, agonistę KOR, wprowadzono po raz pierwszy w Japonii do leczenia świądu mocznicowego, ale ostatnio okazała się skuteczna również w leczeniu świądu cholestatycznego [60, 61]. W momencie gdy lek stanie się dostępny na rynku światowym, charakteryzująca go bardzo mała liczba działań niepożądanych z pewnością zachęci do przeprowadzenia dalszych badań. Nalfurafiny jak na razie nie przebadano w zakresie leczenia jakiejkolwiek postaci świądu związanego z chorobą nowotworową.

\section{Nalokson}

Leki nalokson i jego doustnie czynny kongener naltrekson, dobrze znani antagoniści receptorów opioidowych, wykazały skuteczność w leczeniu świądu cholestatycznego [62]. Jednakże antagoniści wywołują nieprzyjemny zespół abstynencyjny, nawet jeśli pacjenci nie przyjmowali żadnych opioidów [63]. W kontekście świądu związanego z chorobą nowotworową istnieją uzasadnione obawy, że antagoniści opioidów zniosą działanie przeciwbólowe. Przez dziesięciolecia uczono, że skuteczność naloksonu wiąże się $z$ antagonizmem receptorów opioidowych. Jednakże nalokson i naltrekson wiążą się również z receptorami Toll-like (szczególnie TLR-4) i mogą wpływać na związane z tymi receptorami przesyłanie sygnałów pronocyceptywnych, a tym samym na świąd [64]. Ponadto receptory Toll-like nie są stereoselektywne, w związku z czym zastosowanie (+)-naloksonu blokowałoby receptory Toll-like przy jednoczesnym wzmocnieniu efektów działania opioidów [64, 65]. 
Strategia ta wydaje się być obiecująca w przypadku bólu neuropatycznego $[66,67]$ i powinna zostać przebadana również w odniesieniu do świądu. Możliwe, że przeciwświądowe działanie naloksonu i naltreksonu zaobserwowane przez Bergasa i wsp. [68] oparte jest na antagonizmie receptorów Toll-like.

\section{Buprenorfina}

Buprenorfina jest częściowym agonistą MOR i antagonistą KOR [69]. Sugerowano, że wysokie powinowactwo buprenorfiny do MOR uniemożliwiałoby wiązanie rzekomych świądogennych peptydów opioidowych. Niczego takiego nigdy nie udowodniono, ale działanie buprenorfiny jako leku przeciwświądowego sprawdzono w kontrolowanym badaniu klinicznym z użyciem preparatu podawanego pod język [70]. Leczeniu poddano zaledwie 5 pacjentów. Dwóch pacjentów zareagowało dobrze, ale u 3 odnotowano niemożliwe do wytrzymania działania niepożądane. Badanie przerwano. Samą koncepcję jednak rozszerzono na buprenorfinę podawaną przezskórnie i doniesiono o kilku przypadkach korzystnego jej działania w świądzie związanym z chorobą nowotworową [71-73]. Nie podjęto żadnych dalszych badań klinicznych.

Także w tym przypadku należy zauważyć, że oprócz wpływu buprenorfiny na receptory opioidowe, reaguje ona również $z$ receptorami Toll-like i aktywuje TLR-4 w sposób znacznie słabszy niż na przykład morfino-3-glukoronid czy pożywka kontrolna $z$ bakteryjnym LPS [64]. Podsumowując, efekt ten pozostaje nieudowodniony, ale bardzo interesujący z uwagi na fakt, że w przeciwieństwie do naloksonu, buprenorfina nie powoduje zespołu abstynencyjnego i zniesienia działania przeciwbólowego.

\section{Wnioski}

Świąd w przebiegu nowotworu to zjawisko silnie niejednorodne. Spektrum zaczyna się od świądu cholestatycznego, paraneoplastycznego i neuropatycznego, zaś kończy się na świądzie związanym z terapią (nowotworową) (pominiętym w niniejszym przeglądzie). Jest to objaw rzadki, ale tradycyjnie oporny na leczenie. W ostatnim czasie w dziedzinie terapii przeciwświądowej odnotowano znaczny postęp. Niektóre z nowych leków już przetestowano $w$ kontrolowanych badaniach klinicznych, chociaż dane nadal są niewystarczające. Najważniejszą koncepcją jest zapalenie ośrodkowego i obwodowego układu nerwowego związane z receptorami Toll-like. Większość leków, które okazały się skuteczne w leczeniu świądu w przebiegu raka, wykazuje również skuteczne działanie na receptory Toll-like, co sugeruje, że rozwój nowych leków powinien być ukierunkowany głównie na te właśnie receptory. Niestety, rozwój nowych SSRI hamowany jest przez doniesienia o zwiększonej liczbie samobójstw u młodych pacjentów stosujących leki z tej grupy $w$ walce $z$ depresją $[74,75,76]$. Jest jednak możliwe, że w przyszłości zostaną opracowane nowe leki przeciwzapalne o działaniu ośrodkowym, które stosowane będą w leczeniu zarówno świądu, jak i innych chorób neurodegeneracyjnych.

Inne leki skuteczne w leczeniu świądu w przebiegu raka oddziałują na mechanizm przesyłania impulsów w rdzeniu kręgowym i mózgu. Leki te, do których należą między innymi gabapentyna i pregabalina, są znane już od pewnego czasu, ale nie wniosły znacznych zmian do naszego klinicznego postępowania w przypadku świądu. Z drugiej strony, aprepitant, oraz jego nowy, rzekomo opracowywany kongener serlopitant, wykazują obiecujące wyniki, również w przebiegu raka.

Kolejna grupa leków wiąże się z opioidami i antagonistami receptorów opioidowych. W grupie tej bardzo potrzebne są badania dotyczące (+)-naloksonu i (+)-naltreksonu. Należy także przeprowadzić badania dotyczące skuteczności niedawno wprowadzonej do leczenia świądu mocznicowego nalfurafiny w leczeniu świądu związanego z chorobą nowotworową. Badania te są opóźnione z uwagi na fakt, że świąd w przebiegu raka to problem złożony, a jednocześnie stosunkowo rzadki. W leczeniu świądu związanego z chorobą nowotworową nie ma zbyt wiele - lub nawet w ogóle nie ma - miejsca na leki przeciwhistaminowe.

\section{Konflikt interesów}

Autor deklaruje brak konfliktu interesów.

\section{Finansowanie}

Badanie nie było finansowane. 